\title{
Diversity and inclusivity: the way to multidisciplinary intensive care medicine in Europe
}

\author{
Maurizio Cecconi ${ }^{1,2^{*}} \mathbb{D}$, Jozef Kesecioglu ${ }^{3}$ and Elie Azoulay ${ }^{4}$ on behalf of the European Society of Intensive Care \\ Medicine
}

(c) 2021 The Author(s)

Intensive Care was born through a polio pandemic in 1954 in Copenhagen. Today, it is a multidisciplinary, rigorous, precise, teachable, and highly scientific medicine branch. Situations such as the 2009 influenza outbreak, SARS, MERS, Ebola, terrorist attacks have emphasized how critical care teams were committed and devoted to their missions, from public health to individual care. These events reminded political leaders, healthcare administrators, the entire medical community, and the lay public that Critical Care is and will be central in managing such crisis and disasters [1].

Intensive Care organization varies across Europe where the number of intensive care unit (ICU) beds is $11.5 / 100,000$ people but varies from 4.2/100,000 (Portugal) to nearly $30 / 100,000$ (Germany). This variation also applies to nurse ratio: from one to three patients/ nurse according to countries [2]. The need for ICU beds is growing continuously, not only in response to a pandemic but also to our aging societies' needs. Recent medical progress (complex surgical operations, cell therapy with CAR-T cells, etc.) required more ICU beds. During the pandemic, critical care outreach has allowed opening more beds in the wards, where noninvasive respiratory support has been provided [3]. Expanding ICU's beds automatically requires increasing the number of competent, skilled ICU specialists, nurses and other allied professionals. Failure to do so will mean ICU beds' shortage across Europe.

*Correspondence: president@esicm.org

${ }^{1}$ Department of Biomedical Sciences, Humanitas University, Via Rita Levi Montalcini 4, 20090 Pieve Emanuele - Milan, Italy

Full author information is available at the end of the article
Despite Europe being the place where the specialty was born and having a long tradition of clinical, research and educational excellence in intensive care medicine (ICM), Intensive Care Medicine does not exist as a European professional qualification in Annex $\mathrm{V}$ of the Directive 2005/36/EC. It results in part from the different pathways to become an intensivist: different base specialties (anaesthesiology, internal medicine, respiratory medicine, cardiology, neurology, nephrology, surgery, etc.) lead to Critical Care. In some countries, Critical Care is a primary specialty. The European Society of Intensive Care Medicine (ESICM) believes that this diversity has widened the discipline in Europe. Unfortunately, this has also prevented the free movement of intensivists across Europe, allowing only mutual recognition of base specialties. Inability to transfer skilled intensive care specialists is a major weakness for European citizens and intensivists, particularly for the next generation of intensivists.

In November 2020, ESICM contributed a draft consultation paper to include Intensive Care Medicine in Annex V, creating a framework to unfetter intensivist's movements. This paper was shared with the European Commission, that started a preliminary fact-finding mission with a consultation of Member States of the EU. We are grateful to the national and international societies from various disciplines, which have provided feedback on the intensivists' free movement based on diversity and multidisciplinarity. Our proposed framework for Annex V considers existing training pathways to becoming a European intensivist and, if applied, will allow intensivists to work across different countries. Every respondent has made it very clear that what matters the most is that intensivists

\section{Springer}


<smiles>C1CCOCC1</smiles>

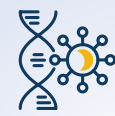
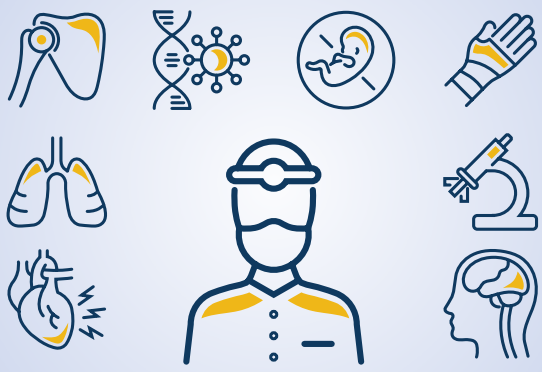

Recognizing ICM as a specialty, keeping existing specialties and give value and recognition to the "intensivist qualification"; multidisciplinarity and inclusiveness are the fundamental values to achieve this.

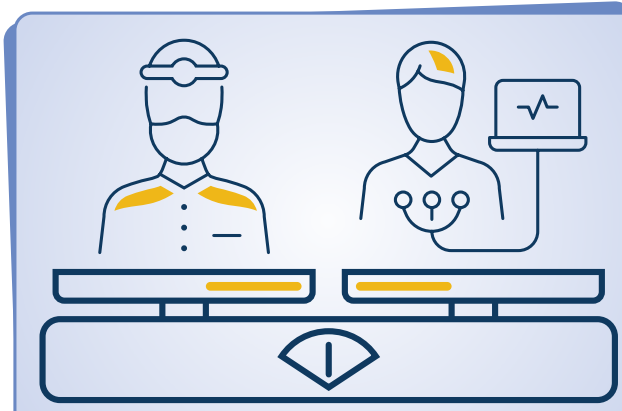

Framing a proposal that stands between the lowest common denominator and the patient's best interest and healthcare workers working conditions.

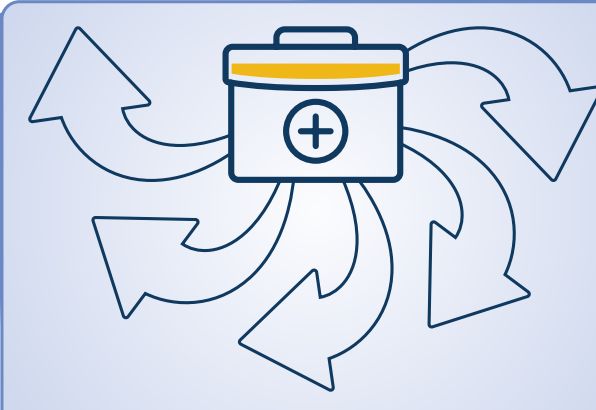

Easing the circulation of intensive care specialists in Europe by standardizing training modalities in quantity and quality (competencies, credentials).
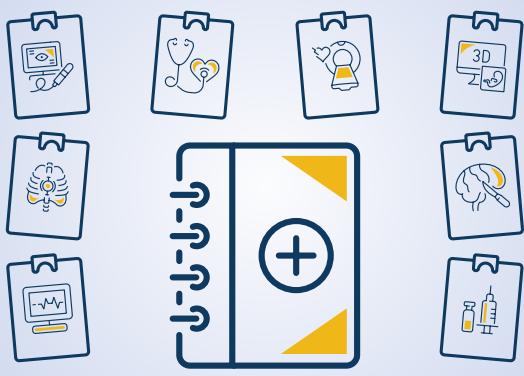

सक

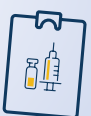

Including all schemes, modalities and intensive care curricula throughout Europe without making one of those the standard. We should learn from each model. This initiative promotes competencies. These competencies should be acquired in an adequate amount of time, both in a primary specialty or in one of the multidisciplinary pathways.

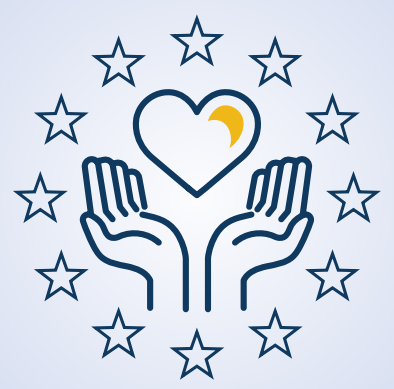

Building a European Health Union dedicated to intensive care. We are committed to shaping the future of critical care in a way that can serve individual and public health, much more than owns (or anyone's) interests. This union will have to address the EU's health security framework and reinforce preparedness and response to the current health crisis and future ones*. We need to take advantage of the high degree of solidarity within the EU Member States throughout and beyond this pandemic.

*https://ec.europa.eu/commission/presscorner/detail/en/ SPEECH_20_1655

Fig. 1 ESICM vision for the free movement of Intensivists in Europe 
are competent in ICM and have spent an adequate amount of time to achieve these competencies. The European Training Requirement of the Union Européenne des Médecins Spécialistes (UEMS), starting with the EU funded Competency Based Training programme in Intensive Care Medicine for Europe (CoBaTriCe) project, [4-6] represent a solid base for a common syllabus of these competencies (https:// www.uems.eu/_data/assets/pdf_file/0007/19753/ Item-3.2.1-ETR-Training-requirements-in-ICM-final26-sept-2014.pdf).

Following the pandemic emergency, we need to rebuild based on what we learned, shape the future of intensive care, and protect the next generations. The time is now to think innovatively. A pragmatic and functional European Health Union is mandatory to respond to pandemics and disasters. As critical care clinicians, we are concerned about patient's outcomes. European citizens share these concerns and expect safeguards from a single voice, rallied actions, and effective results.

As ESICM, we are committed to optimizing the existing situation.

Together we are Intensive Care. Together we have a unique opportunity to acknowledge the importance of ICM for our healthcare systems and to find a structured, flexible and long-term solution to this issue urgently. This solidarity will have to build the safest possible model for patients and providers. We must rebuild European citizens' trust by offering the best possible healthcare service. People count on us; we cannot miss this opportunity. Facilitating intensivists' free movement across EU countries has been advocated for a long time by ESICM. This initiative allows ICU specialists to freely operate within the EU, sharing knowledge and competences, ultimately improving care standards. ESICM believes that the Intensive Care Medicine's inclusion using a "novel approach" to Annex V of the Directive on the Recognition of Professional Qualifications (2005/36/ EC) will represent significant progress towards the rapid recognition of these essential healthcare professionals [7].

In summary the European Society of Intensive Care Medicine

- Is aware that it will be a long journey to heal our healthcare systems and economies. However, we cannot wait longer to address the medical community's warning signals about the lack of beds and trained specialists. Suboptimal intensive care is associated with adverse outcomes, healthcare workers exhaustion, and professional leave [8].

- Will continue promoting a multidisciplinary, diverse, and inclusive ICM vision (Fig. 1). ESICM is convinced that the variety of base specialties can only widen and improve intensive care delivery.

- Urges for the free movement of ICU specialist inside Europe (in times of crisis or as a personal choice).

- Urges for the recognition of ICM as an entire profession in the European directive (2005/36/UE annex V)

- Advocates that, whatever pathway, i.e., a primary specialty or a subspecialty of 2 years of Intensive care training (within, on top or across the base specialty), everyone, as long as competencies are achieved, should be recognized a European Intensivist.

- ESICM advocates that European Intensivists should be able to work in different countries as long as the competencies have been achieved.

The free movement of Intensivists in Europe is something we owe to European Citizens and Intensivists in Europe. Diversity and inclusivity are the two values that needs to guide the path to multidisciplinary ICM in Europe.

\begin{abstract}
Author details
${ }_{1}^{1}$ Department of Biomedical Sciences, Humanitas University, Via Rita Levi Montalcini 4, 20090 Pieve Emanuele - Milan, Italy. ${ }^{2}$ IRCCS Humanitas Research Hospital, Via Manzoni 56, 20089 Rozzano - Milan, Italy. ${ }^{3}$ Department of Intensive Care Medicine, University Medical Center Utrecht, Utrecht, the Netherlands. ${ }^{4}$ Médecine Intensive et Réanimation, PHP, Hôpital Saint-Louis, Paris University, Paris, France.
\end{abstract}

\section{Declarations}

\section{Conflicts of interest}

$\mathrm{MC}$ is the ESICM President, JK is the immediate ESICM Past President, and EA is the ESICM President Elect. No other COI.

\section{Open Access}

This article is licensed under a Creative Commons Attribution-NonCommercial 4.0 International License, which permits any non-commercial use, sharing, adaptation, distribution and reproduction in any medium or format, as long as you give appropriate credit to the original author(s) and the source, provide a link to the Creative Commons licence, and indicate if changes were made. The images or other third party material in this article are included in the article's Creative Commons licence, unless indicated otherwise in a credit line to the material. If material is not included in the article's Creative Commons licence and your intended use is not permitted by statutory regulation or exceeds the permitted use, you will need to obtain permission directly from the copyright holder. To view a copy of this licence, visit http://creativecommons.org/licen ses/by-nc/4.0/. 


\section{Publisher's Note}

Springer Nature remains neutral with regard to jurisdictional claims in published maps and institutional affiliations.

Received: 11 March 2021 Accepted: 12 March 2021

Published online: 29 April 2021

\section{References}

1. Wunsch H (2020) The outbreak that invented intensive care. Nature. https://doi.org/10.1038/d41586-020-01019-y

2. Rhodes A, Ferdinande P, Flaatten $\mathrm{H}$ et al (2012) The variability of critical care bed numbers in Europe. Intensive Care Med 38:1647-1653. https:// doi.org/10.1007/s00134-012-2627-8

3. Arabi YM, Azoulay E, Al-Dorzi HM et al (2021) How the COVID-19 pandemic will change the future of critical care. Intensive Care Med 47:282-291. https://doi.org/10.1007/s00134-021-06352-y

4. Bion J, Rothen HU (2014) Models for intensive care training. A European perspective. Am J RespirCrit Care Med 189:256-262. https://doi.org/10. 1164/rccm.201311-2058CP
5. COBATRICE Collaboration (2011) International standards for programmes of training in intensive care medicine in Europe. Intensive Care Med 37:385-393. https://doi.org/10.1007/s00134-010-2096-x

6. COBATRICE Collaboration (2009) The educational environment for training in intensive care medicine: structures, processes, outcomes and challenges in the European region. Intensive Care Med 35:1575-1583. https:// doi.org/10.1007/s00134-009-1514-4

7. Richards GA, Sprung CL, European Society of Intensive Care Medicine's Task Force for intensive care unit triage during an influenza epidemic or mass disaster (2010) Chapter 9. Educational process. Recommendations and standard operating procedures for intensive care unit and hospital preparations for an influenza epidemic or mass disaster. Intensive Care Med 36(Suppl 1):S70-79. https://doi.org/10.1007/s00134-010-1768-x

8. Meier DE, Back AL, Morrison RS (2001) The inner life of physicians and care of the seriously ill. JAMA 286:3007-3014. https://doi.org/10.1001/ jama.286.23.3007 